ELORE (ISSN 1456-3010), vol. $14-1 / 2007$.

Julkaisija: Suomen Kansantietouden Tutkijain Seura ry.

[http://www.elore.fi/arkisto/1_07/knu1_07.pdf]

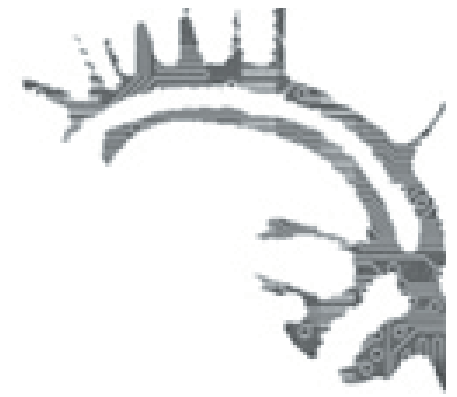

\title{
KIRJA-ARVIO: \\ SIIVOOJANAISET JA KOTIAPULAISET LOPPUMATTOMIEN TEHTÄVIEN ÄÄRELLÄ
}

Käyhkö, Mari 2006: Siivoojaksi oppimassa: etnografinen tutkimus työläistytöistä puhdistuspalvelualan koulutuksessa. Joensuu: Joensuu University Press. 285 sivua.

Kilkki, Minna 2006: Kotiapulaiset. Muistoja sadan vuoden takaa. Kansanelämän kuvauksia 69. Helsinki: Suomalaisen Kirjallisuuden Seura. 319 sivua.

\section{$\underline{\text { Maarit Knuuttila }}$}

Kirjoittaessani tätä kirja-arviota asunnossani siivoilee Hong Li, nainen kaukaa köyhästä Länsi-Kiinasta. Hän on tullut työn perässä varakkaaseen itään. Hänellä tuskin on ammatillista siivoojakoulutusta. Työtä saa silti helposti. Kiinassa työ siivoojana tai kokopäiväisenä kotiapulaisena - ayina - on tie sosiaaliseen nousuun. Hong Li säästää palkastaan koulurahoja tyttärelleen, jotta tämä voi aikanaan saada kunnollisen koulutuksen ja sitä kautta hyvän työpaikan. Tytär tuskin tulee seuraamaan äitinsä jalanjälkiä, uusintamaan "työväenluokkaisuuttaan". Suomessa 1800-luvulla ja vielä pitkälle 1900luvullakin maalaistyttö saattoi samalla tapaa lähteä herrasväkeen piikomaan. Palveluskokemus saattoi johtaa pitokokiksi ja toisinaan hyviin naimisiin: "Sisäpiiat vanhassa pappilassa olivat siinä määrin suosittuja, että esimerkiksi 'Iita' ja 'Hilta', pari vuotta opiskeltuaan hienoa käytöstä, kelpasivat forstmestarien rouviksi ja oppivat puhumaan 'ruohtia melekein yhtä viinisti kuin ruustinna'!' (Kianto (1962 [1922], 299). Sosiologi Mari Käyhkön suomalaiskontekstissa toteutettu väitöstutkimus Siivoojaksi oppimassa. Etnografinen tutkimus työläistytöistä pubdistuspalvelualan koulutuksessa nostaa esille naiskohtaloita, jotka näyttävät tutkimuksen mukaan olevan "perinnöllisiä" ja uusiutuvia. Eikö koulutus olekaan 2000-luvun suomalaisnaiselle tie sosiaaliseen nousuun? 


\section{SiIVOOJANAiSET JA KOtiAPULAISET LOPPUMATTOMIEN TEHTÄVIEN ÄÄRELLÄ}

\section{ETNOGRAFIAA LUOKKAHUONEISSA}

Käyhkö on tutkinut 20 työläistaustaisen nuoren naisen kouluttautumista siivoojaksi sekä sitä, miten nämä siivoojakoulutetut naiset työssä ollessaan merkityksellistävät koulutuksensa, työelämänsä ja äitiytensä. Tutkimusote on etnografinen, eli Käyhkö on osallistunut siivoojanaisiksi kouluttautuvien tyttöjen päivittäiseen elämään toisen asteen ammatillisessa oppilaitoksessa. Toisinaan hän on aivan konkreettisesti tarttunut jopa harjan varteen. Kenttätöiden lisäksi tutkija on myöhemmin haastatellut kouluttautujaryhmän jäseniä saadakseen selville, mitä ammattiin valmistumisen jälkeen tapahtui. Metodiset valinnat ovat paikallaan, kun Käyhkön keskeinen tavoite on "tehdä näkyväksi yhteiskuntamme näkymättömissä ja kuulumattomissa olevaa työväenluokkaista tyttöyttä ja naiseutta, tämän kulttuurisen naiseuden olemusta ja paikkaa yhteiskunnassamme sekä työläisnaiseksi kasvattamista ja kasvamista" (s. 14). Voidaan ajatella, että siivoojan ammattityö on täynnä juuri sellaisia itsestäänselvyyksiä ja hiljaisuuksia, jotka jäävät monin osin sanallistamatta. Toisaalta haastattelujen kautta tutkittavilla itsellään on mahdollisuus kertoa kokemuksistaan ja niistä merkityksellistämisistä, joita Käyhkö ajaa takaa. Onkin varsin ilahduttavaa, että tutkija rohkenee jättää tutkijankammionsa ja astua tutkittaviensa pariin ottamaan selvää siitä, mitä kulttuuristen pintarakenteiden alla piilee. Tutkimuksessa on käytetty myös muita aineistoja, kuten oppilaitoksen oppi- ja esittelymateriaalia. Tietysti olisi ollut toivottavaa, että tutkija olisi tehnyt kenttätyötä syvemmin ja lähtenyt kokeilemaan, millainen siivoojan asema työyhteisössä todella on. Mutta näinkin toteutettuna omakohtaiset kenttätyöt ovat arvokas kokemus.

Lukijana olisin toivonut, että aineisto olisi koodattu tarkemmin. Olisi ollut mielenkiintoista nähdä, missä määrin kutakin haastattelua on käytetty. Lisäksi lukijalle olisi tarjoutunut tilaisuus nähdä paremmin kertovia yksilöitä. Kun Käyhkö kuitenkin tahtoo kuvata yksilöitä yleisempää, on ratkaisu tässä tapauksessa perusteltu.

Tutkimus paikantuu (koulutus)sosiologian, feministisen tutkimuksen ja tyttötutkimuksen kentille. Valittu tieteellinen monikerroksellisuus onkin paikallaan, sillä ammatillinen koulutus ei ole yhtenäinen kenttä ammatinvalinnasta puhumattakaan. Tutkija haluaa myös tuoda esille sen, että koulutukselliset valinnat ovat usein edelleenkin sukupuolisidonnaisia ja sukupuolijärjestelmää uusintavia. Tutkimuksen yksi keskeinen käsite on työväenluokkaisuus ja tästä johdettuna kysymys siitä, kuinka työväenluokkaisuus koulutuksen kautta uusintaa itseään. Kuten Käyhkö toteaa, luokka a-käsitteen käyttö ei ole aivan ongelmatonta. Ehkä käsitteen käyttöä ei tarvitsisi kyseenalaistaa perinteisissä luokkayhteiskunnissa, kuten Isossa-Britanniassa. Käsitteen käyttö suomalaiskontekstissa on kuitenkin eri asia. Tutkija koettaa perustella työväenluokkaisuutta monin eri perustein, mutta jollakin tapaa ne tuntuvat hieman haetuilta. Perusteina luokkautumiselle hän esittää tutkittavien kotitaustaa ja erityisesti vanhempien koulutustasoa sekä ammattia tai työtehtäviä. Käyhkö ottaa esille myös työväenluokkaisuuden kulttuurina (vrt. Willis 1984). Tulee kuitenkin muistaa, että vielä 1800- ja 1900-lukujen vaihteessa vain noin $4 \%$ koko suomalaisväestöstä sai elantonsa teollisuudesta joko suoraan tai välillisesti (Suomen virallinen tilasto 1904, 127). Iso-Britannia teollistui Suomea aiemmin, ja työläisväestön alakulttuurilla on siellä näin huomattavasti vankemmat ja vakiintuneemmat juuret. Voidaankin miettiä 
sitä, voiko yhdessä tai kahdessa sukupolvessa syntyä niin voimakkaita kulttuurisia tapoja ja perinteitä, jotka perustelisivat luokka-käsitteen käyttöä. Lisäksi juuri työväenluokkaisuuden "periytyminen" tuo mukanaan ongelmia silloin, kun esimerkiksi isovanhempien, vanhempien ja tutkittavien sisarukset suljetaan tutkimuksesta pois. Toisaalta luokka-käsitteen käyttäminen on ehkä kuitenkin paikallaan, kun Käyhkön tapaan halutaan purkaa vallitsevia ja näin ollen usein "näkymättömiä" kulttuurisia käytänteitä.

\section{KÄYTÄNTEISIIN PIILOUTUVIA NAISPERINTEITÄ}

Tutkimus jakautuu viiteen osaan, joista aineisto-osuuksia on kolme: "Kuinka meistä tuli siivoojia?", "Kasvatus ja moraalinen säätely" sekä "Kaksinainen ammattioppi". Ensimmäinen aineisto-osuus seurailee nuorten naisten koulutuksen etenemistä puhdistuspalvelualan ammattilaisiksi. Käyhkö purkaa ansiokkaasti stereotyyppistä käsitystä, jonka mukaan pojat ovat koulussa viihtymättömiä "ongelmaoppilaita" ja tytöt vastaavasti sopeutuvia, kilttejä ja ahkeria. Myös tyttöjen keskuudessa on niitä, joille koulunkäynti ei välttämättä ole ongelmatonta. He eivät Käyhkön mukaan viihdy koulussa eivätkä ole juuri tietoisia tulevasta ammattiurastaan. He tavoittelevat kyllä ammatillista koulutusta, mutta eivät tahdo "hukata elämäänsä koulunkäyntiin" (s. 52). Nopea työhön pääsy näyttää ensisijaiselta tavoitteelta. Kuitenkin aineistoa lukiessa näyttää myös siltä, että kouluttautumisvastaisuus ei olekaan niin ilmeistä, minä tutkija sen esittää. Tytöt tuovat esille sen, että ensimmäinen koulutusvalinta ei välttämättä ole lopullinen vaan portti opintoihin ylipäätään. Toisenlaisia reittejä joudutaan miettimään silloin, kun ei täytetä koulumaailman odotuksia ja kun opettaja- tai opinto-ohjaajakunta edelleen jakaa oppilaita joko teoreettisesti tai käytännöllisesti suuntautuviksi. Käyhkön havainnot haastavat varmasti miettimään tarkemmin sitä, voitaisiinko kouluttautumisura nähdä muunkinlaisena kuin perinteisenä putkena. Voisiko elinikäinen oppiminen tai "pätkäoppiminen" toimia käytännössä eikä vain juhlapuheissa? Tosin Käyhkön tutkimien siivoojanaisten valmistuttua ammattiinsa moni oli sitä mieltä, ettei enää kaipaa koulunpenkille takaisin, vaikka työelämä osoittautuikin osin pettymyksiksi, pätkätöiksi, osa-aikaisuuksiksi ja työttömyydeksi.

Tutkimuksen toisessa aineisto-osuudessa käsitellään siivoojanaiseksi kasvattamista ja erityisesti sitä, millaista "puhtautta" (siivooja)naisilta odotetaan sekä mentaalisesti että ruumiillisesti. Luku painottuu moraalikasvatukseen aina tyttöjen käytöksestä työelämän "näkymättömäksi" naiseksi. Tutkija käy läpi niitä vaateita, joita puhdistuspalvelualan koulutettaviin kohdistetaan. Halutut työntekijän ominaisuudet - täsmällisyys, rehellisyyden, ahkeruus ja sisukkuus - lienevät aivan tavallisia missä tahansa asennekoulutuksessa. Sinällään luku ei ensilukemalta tarjoa mitään uutta myöskään sen suhteen, kuinka naisen ruumista ja päänsisäistä hygieniaa on haluttu kontrolloida. Yllättävää kuitenkin on se, että mikään ei tässä kontrollointihalussa ole ratkaisevasti muuttunut viimeisen sadan vuoden aikana, kuten Käyhkö osoittaa. Tutkimus tuo esille myös osan siitä, millainen on ylipäätään ammatillisen koulujärjestelmän "sukupuolineutraalin" taakse piiloutuva nais- tai mieskuva. 


\section{SiIVOOJANAiSET JA KOTIAPULAISET LOPPUMATTOMIEN TEHTÄVIEN ÄÄRELLÄ}

Viimeinen aineistoluku on kaksiosainen. Tutkija tarkastelee naisten epävirallista koulutusta ja kasvatusta tulevaan kotiin ja äitiyteen. Lopuksi tuodaan esille se, miten työläisnaiset itse määrittelevät paikkansa yhteiskunnassa. Käyhkön tutkimus pureutuu tässä luvussa mielenkiintoisella tavalla naisille suunnatun ammatillisen koulutuksen jatkumoihin ja perinteisiin. Käyhkö osoittaa, että puhdistuspalvelualalla opiskelevia nuoria naisia kasvatetaan toisaalta ammattiin mutta toisaalta edelleen myös äideiksi ja vaimoiksi lähes samalla tapaa kuin 1800-luvun loppupuolella. Tutkimus näyttää sen, että eri alojen koulutuksella on omanlaisensa historia ja sen myötä syntyneet perinteet, jotka elävät - jos eivät aivan ilmimuodossaan, niin ainakin piiloisesti erilaisissa käytänteissä. Onkin aivan selvää, että erilaiset käytänteet kantavat menneisyyttään mukanaan. Lattian lakaisulla ja pölyhuiskan heiluttamisella on niilläkin oma historiansa. Jokaista käytännettä ei kukin uusi sukupolvi keksi uudelleen. (Vrt. Knuuttila 2006.) On kuitenkin merkillepantavaa, miten tietyt käytänteet kantavat mukaan myös naistai mieskulttuurisia perinteitä. Tässä mielessä kunkin sukupolven olisi syytä miettiä, mikä perinteissä on jatkamisen arvoista ja mikä ei.

Käyhkö kirjoittaa, että "ihmisten olemista ja käyttäytymistä tulkitaan herkästi sukupuolittuneiden stereotypioiden lävitse” (s. 23). Samankaltaista stereotyyppistä tulkintaa harjoitetaan toki monen muunkin asian, kuten ammattikuvien, suhteen. On ilahduttavaa, että tutkija on pyrkinyt tuomaan esille yhteiskunnan "näkymättömiä" ja vaie(nne)ttuja. Kuitenkin olisin odottanut neutraalimpaa ja arvostavampaa otetta siivoustyöhön. Vaikka tutkimuksesta voidaan lukea, että tutkija kunnioittaa tutkittaviaan, olisi ollut paikallaan tuoda esille myös siivoustyön tärkeyttä ja sen vaatimaa spesifiä ammattitaitoa. Se, miten jossakin kulttuurisessa tilassa tai historiallisessa ajassa jokin toimi arvotetaan, on vaihtelevaa. Siivoustyön arvostuksen nousulle, samoin kuin muillekin naisvaltaisille ammateille, tulee antaa mahdollisuus liikahtaa kulttuurisissa arvojärjestelmissä. On merkittävää, että ammatillisesta koulutuksesta tehdään tutkimuksia, jotka paljastavat opetukseen ja koulutukseen hautautuneita arvoja, arvostuksia sekä Käyhkön tutkimustapauksessa koulutukseen hautautunutta moraalista säätelyä. Vaikka tutkimus ei keskity opettamiseen vaan oppimiseen, antaa se varmasti jokaiselle opettajalle ajattelemisen aihetta kysyen sitä, mitä siellä koulussa itse asiassa opitaankaan.

\section{KOTIHENGETTÄRIÄ, VARAÄITEJÄ JA PIKKUPIIKOJA}

Hieman erilaisen näkökulman naisten perinteisiin kotitöihin luo Minna Kilkin toimittama antologia Kotiapulaiset. Teokseen on koottu 37 kertomusta kotiapulaismuistoaiheisesta kilpakeruusta, jonka järjesti Miina Sillanpään Säätiö yhteistyössä Suomalaisen Kirjallisuuden Seuran ja Kotiliesi-lehden kanssa vuosina 2004-2005. Kirjoituksia kertyi kaiken kaikkiaan 379 kappaletta. Kilkki on koonnut antologiaan kirjoituksia, jotka kertovat kotiapulaisista hieman eri näkökulmista.

Ensin teoksessa annetaan muisteluvuorot sekä kirjoittajille, jotka muistelevat "varaäitejän̈n", herttaisia ja rakastavia kotihengettäriä, että kotiapulaisten työnantajille. 


\section{MaARIT KNUUTTILA}

Useassa kertomuksessa perheen kotiapulainen hahmottuu melkeinpä rakkaammaksi kuin oma äiti. Kotiapulainen oli aina läsnä, ja usein hänen ja lapsen välille muodostui elinikäinen kiintymys- ja ystävyyssuhde. Yksi kertojista tulkitsee, että kiiinteä suhde ei ehkä kuitenkaan johtunut vain kotihengettäristä vaan myös siitä, että lapsuudessa oli aina mahdollista olla kotona turvallisissa oloissa. Lapsuusmuistot kotiapulaisista ovat ylipäätään herttaisia ja ikään kuin vanhoista suomalaisista elokuvista huviloineen, aurinkoisine kesineen sekä maitoa ja voileipää keittiössä passaavine piikoineen.

Kun kotiapulaisten työnantajat saavat puheenvuoron, kaunis kotiapulaiskuva hieman jo säröilee. Esille tulevat uskollisten kotihengetärten myötä myös ne tytöt, jotka eivät jostain syystä täyttäneet isäntäperheen toiveita. Oli papiljotit päässä nukkuvia kynnenlakkaajia, huvituksissa kävijöitä, laiskureita ja hutiluksia. Oli ilmeisesti myös Herkän kaltaisia tyttöjä, jotka pyöräyttelivät lapsia puolivahingossa. Näin Herkkä puolusteli itseänsä: "Voi, voi, rouva, kun mie oon niin herkkä, että aina kun mie oon miesten kanssa sellasissa suhteissa, mie saan lapsen" (s. 32).

Työnantajien kertomuksissa kuvastuu myös se, miten kotiapulais-instituutio hiljalleen muutti muotoaan. Kotiavun palkkaaminen muuttui 1960- ja 1970-luvulta lähtien monimutkaiseksi veroineen ja eläkemaksuineen. Palkat henkilösivukuluineen kohosivat hiljalleen niin suuriksi, että yleensä työssäkäyvän äidin ansiotulo meni lähes kokonaisuudessaan apulaisen palkkaan. Kirjassa tuodaan esille myös kotiapulaisena olon uusia muotoja eli palvelua au pair -tyttöinä ulkomaalaisperheissä.

Kotiapulaisina palvelleiden kertomuksia kertyi kaikkiaan 140. Teokseen valikoituneet kirjoitukset on sijoitettu kirjan loppupuolelle. Näistä kertomuksista voidaan lukea monenlaisista työurista ja elämänkuluista. Kaksi selkeää linjaa on kuitenkin havaittavissa. Kotiapulaisena oltiin lähes koko työura, usein joko yhdessä tai kahdessa perheessä. Monille kotiapulaisaika oli toisaalta ikään kuin välivuosi. Se oli siirtymä maalaiskylästä kaupunkiin ja kansa- tai oppikoulusta ammatilliseen koulutukseen. Onpa kirjoituksista luettavissa myös eräänlaisia Juurakon Hulda-tarinoitakin. Huldahan oli professorilla palveluksessa ja luki salaa yökaudet professorin kirjoja ja kouluttautui iltakoulussa maisteriksi asti.

Kokemukset ovat kotiapulaisten kertomuksissa vaihtelevia aivan samoin kuin työnantajienkin kuvauksissa. Oli julmia emäntiä ja toisaalta niitä, joista tuli rakkaita ystäviä. Toisissa perheissä kotiapulainen oli arvostettu perheenjäsen, toisissa alistettu piikatyttö. Monet tuovatkin esille, että aika kotiapulaisena oli hyvin rankkaa ja väsyttävää. Usein sitä väritti vielä syvä ikävä kotiin. Kuitenkin suurin osa muistelijoista on sitä mieltä, että juuri ankarat ja ankeat olot kasvattavat kunnon ihmisiksi ja antavat "paksupohjaiset kengät tallata rosoisiakin teitä" (s. 256).

\section{KirjallisuUs}

KIANTO, ILMARI 1962: Vanha pappila. Helsinki: Otava. [1922]

KNUUT'TILA, MAARIT 2006: Kansanomainen keittämisen taito. Kansatieteellinen Arkisto 50. Helsinki: Suomen Muinaismuistoyhdistys. 
SiIVOOJANAiSET JA KOTIAPULAISET LOPPUMATTOMIEN TEHTÄVIEN ÄÄRELLÄ

SUOMEN VIRALLINEN TILASTO 1904. Katsaus Suomen taloudelliseen tilaan. Viisivnotiskausi 1896-1900. Helsinki: Keisarillisen senaatin kirjapaino.

WILLIS, PAUL 1984: Koulunpenkiltä palkkatyöhön. Tampere: Vastapaino.

FT Maarit Knuuttila toimii vapaana tutkijana Suzhoussa, Kiinassa. 